\title{
Characterisation of methicillin-resistant isolates of Staphylococcus aureus by analysis of whole-cell and exported proteins
}

\author{
FIONA M. THOMSON-CARTER and T. H. PENNINGTON
}

Department of Bacteriology, University of Aberdeen Medical School, Foresterhill, Aberdeen AB9 2ZD

\begin{abstract}
Summary. Thirty-four isolates of methicillin-resistant Staphylococcus aureus (MRSA) from patients in Glasgow Royal Infirmary were studied. Whole-cell protein profiles obtained by sodium dodecyl sulphate-polyacrylamide gel electrophoresis (SDSPAGE) were compared with banding patterns produced by immunoblots of exported proteins. Human plasma was used as a source of staphylococcal antibodies for the immunoblots. SDS-PAGE of whole-cell extracts did not usefully distinguish different isolates of MRSA. Reproducible banding patterns were obtained by immunoblots of exported proteins. Analyses of immunoblots by use of the Dice coefficient demonstrated that isolates of MRSA could be divided into two main groups. Immunoblots of exported proteins provided a rapid, reproducible and sensitive method for characterisation of MRSA.
\end{abstract}

\section{Introduction}

Methicillin-resistant strains of Staphylococcus aureus (MRSA) were reported in Britain shortly after the introduction of methicillin (Barber, 1961; Jevons, 1961). Since the 1960s, MRSA have caused major nosocomial infections world-wide, most recently in Italy (Gelmi et al., 1987), the German Democratic Republic (Witte et al., 1986), the United Kingdom (Bradley et al., 1985), the United States of America (Locksley et al., 1982) and Australia (Pavillard et al., 1982). Further significant outbreaks have been reported elsewhere (Casewell, 1986).

Despite the clinical importance of MRSA, a satisfactory scheme for the characterisation of strains has yet to be established. Various properties of MRSA have been investigated in attempts to facilitate typing-e.g., pigmentation (Lacey and Stokes, 1979); biochemical characteristics (Peacock et al., 1981; Vickery et al., 1983) lipolytic activity and metal ion resistance (Grieble et al., 1981); esterase polymorphisms (Branger and Goullet, 1987); susceptibility to lysis by phage (Marples et al., 1986; Vickery et al., 1986; Witte and Braulke, 1987; Richardson et al., 1988); and possession of plasmids conferring resistance to antibiotics (Dowd et al., 1983; Gillespie et al., 1984; Lyon et al., 1984; Gelmi et al., 1987). However, results obtained by

Received 12 May 1988; accepted 4 July 1988. these methods have proved difficult to interpret for the following reasons: biochemical tests did not assist strain differentiation (Vickery et al., 1983); loss of susceptibility to certain routine phages (Lacey and Stokes, 1979; Marples et al., 1986); significant numbers of MRSA isolates were nontypable with routine phage panels (de Saxe et al., 1983); non-typability with routine phages has necessitated the introduction of additional test phages (Vickery et al., 1983; Marples and Cooke, 1985) and rapid spread of plasmids among MRSA has been observed to alter both plasmid profiles and antibiotic resistance (Gillespie et al., 1984). Other techniques such as electrophoresis of polymorphic enzymes (Branger and Goullet, 1987) involve lengthy experimental procedures. Analyses of MRSA whole-cell polypeptides by ${ }^{35} \mathrm{~S}$-sodium dodecyl sulphate-polyacrylamide gel electrophoresis (SDS-PAGE) were unable to discriminate different strains (Stephenson et al., 1986).

Immunoblotting of bacterial whole-cell polypeptides, by the Western blot technique, has been suggested as a method for "fingerprinting" pathogens (Burnie and Matthews, 1987). Poxton et al. (1984) used immunoblotting to characterise different strains of Clostridium difficile, and MRSA isolates have been divided into eight groups according to their whole-cell immunoblot profile (Lee and Burnie, 1988). In an alternative approach, immunoblotting of exported proteins has also been used successfully to type isolates of $S$. aureus 
(Krikler et al., 1986). The aim of the present study was to compare different MRSA isolates by SDSPAGE of whole-cell proteins, and by immunoblotting of exported proteins.

\section{Materials and methods}

\section{Bacterial strains}

MRSA isolates from 34 patients were obtained from Dr J. Coia, Glasgow Royal Infirmary. All isolates were identified as $S$. aureus on the basis of colonial morphology, positive coagulase and Staphaurex ${ }^{\circledR}$ latex agglutination tests (Coia et al., personal communication). Phage typing was performed at the Central Public Health Laboratory, Colindale, UK, with routine and experimental phages.

\section{Preparation of samples}

Isolates of MRSA were plated out on nutrient-agar plates and incubated at $37^{\circ} \mathrm{C}$ for $24 \mathrm{~h}$. A sweep of colonies from these plates sufficient to give approximately $2 \mu \mathrm{g}$ bacterial dry weight $/ \mathrm{ml}$ was inoculated into $150-\mathrm{ml}$ volumes of nutrient broth and incubated at $37^{\circ} \mathrm{C}$ overnight in an orbital incubator. The resulting broth cultures were centrifuged at $10000 \mathrm{~g}$ for $15 \mathrm{~min}$ at $4^{\circ} \mathrm{C}$ and the upper $10 \mathrm{ml}$ of each supernate was retained for gel analysis. The remainder of each supernate was discarded. The cell pellets were resuspended in 10-ml volumes of distilled water and washed by centrifugation at $2500 \mathrm{~g}$ for $15 \mathrm{~min}$ at $25^{\circ} \mathrm{C}$. After resuspension in $1-\mathrm{ml}$ volumes of distilled water, the pellets were washed again at $9000 \mathrm{~g}$ for $5 \mathrm{~min}$ at $25^{\circ} \mathrm{C}$. The pellets were finally resuspended in an equivalent volume of sterile distilled water, placed in an ice bath and sonicated for $5 \mathrm{~min}$ with an ultrasonic probe (Rapidis 150, Ultrasonics Ltd, Shipley, England) emitting $45 \mathrm{~W}$ at maximum power. Whole-cell sonicates were stored at $-70^{\circ} \mathrm{C}$, culture supernates were stored at $-20^{\circ} \mathrm{C}$. Protein concentrations were estimated by the method of Lowry et al. (1951).

\section{Sodium dodecyl sulphate-polyacrylamide gel electrophoresis (SDS-PAGE)}

Whole-cell sonicates and culture supernates were analysed by a modified version of the SDS-PAGE technique of Laemmli (1970). Samples were prepared for PAGE by mixing in proportions of two parts sample to one part $0.5 \mathrm{M}$ Tris-HCl, $\mathrm{pH} 6 \cdot 8$, containing SDS $6 \%$ $\mathrm{w} / \mathrm{v}$, glycerol $30 \% \mathrm{w} / \mathrm{v}, 2-$ mercaptoethanol $15 \% \mathrm{w} / \mathrm{v}$, and bromophenol blue $0.001 \% \mathrm{w} / \mathrm{v}$ and boiling for $5 \mathrm{~min}$. Solubilised samples, containing an average of $120 \mu \mathrm{g}$ and $40 \mu \mathrm{g}$ protein for whole-cell extracts and culture supernates respectively, were applied to wells in a $3.6 \%$ acrylamide stacking gel over a $10 \%$ acrylamide separating gel. Electrophoresis was performed with a discontinuous buffer system in a BRL gel apparatus, model V16-2 (BRL, Gaithersburg, MD, USA). The gel was run at a constant current of $30 \mathrm{~mA}$ until the bromophenol blue marker had reached the bottom, a period of 4-5 h. Whole-cell polypeptide gels were stained with Coomassie Brilliant blue R (Sigma) $0.25 \%$ w/v in methanol : acetic acid: water $(45: 10: 45 \mathrm{v}: \mathrm{v})$ and destained in the same solvent mixture before being swollen to original size in acetic acid $7 \% \mathrm{v} / \mathrm{v}$.

\section{Immunoblotting}

Proteins from culture supernate gels were blotted on to nitrocellulose membranes in $25 \mathrm{~mm}$ Tris- $\mathrm{HCl}, 192 \mathrm{mM}$ glycine buffer, $\mathrm{pH} 8 \cdot 3$, containing methanol $20 \% \mathrm{v} / \mathrm{v}$ (Burnette, 1981). Transfer was effected with a current of $100 \mathrm{~mA}$ overnight in a Bio-Rad Transblot cell. Free protein sites were saturated by incubation in blocking buffer containing newborn calf serum (Gibco, Paisley, Scotland) $10 \% \mathrm{v} / \mathrm{v}$ in phosphate-buffered saline, $\mathrm{pH} 7 \cdot 4$, Triton $X-100 \quad 0 \cdot 2 \% \mathrm{v} / \mathrm{v}$ for $30 \mathrm{~min}$. The nitrocellulose membrane was then incubated in human plasma diluted 1 in 50 in blocking buffer for $1.5 \mathrm{~h}$. Several samples of human plasma known to contain antibodies against a large number of staphylococcal polypeptides were pooled to provide test plasma (Krikler et al., 1986). After washing three times for $15 \mathrm{~min}$ each in phosphate-buffered saline, $\mathrm{pH} 7 \cdot 4$, Triton X-100 0.2\% v/v the nitrocellulose membrane was incubated with horseradish peroxidase-linked sheep anti-human IgG serum (Scottish Antibody Production Unit, Carluke, Scotland), diluted 1 in 1000 in blocking buffer, for $45 \mathrm{~min}$. After three further washes of 15 min each in phosphate-buffered saline, $\mathrm{pH} 7 \cdot 4$, Triton $\mathrm{X}-1000 \cdot 2 \% \mathrm{v} / \mathrm{v}$ the nitrocellulose membrane was rinsed in phosphate-buffered saline alone and stained with diamino-benzidine tetrahydrochloride (B.D.H., Poole, England) $0.05 \% \mathrm{w} / \mathrm{v}$ in $0.1 \mathrm{M}$ Tris- $\mathrm{HCl}, \mathrm{pH} 7.6$, containing hydrogen peroxide $0.01 \% \mathrm{v} / \mathrm{v}$.

\section{Comparison of Coomassie-stained and immunoblot protein profiles}

The average similarity between any two staphylococcal isolates represented by either Coomassie-stained gels or immunoblots was assessed by use of the coefficient of Dice (1945), whereby

average percentage similarity $(\% \mathrm{~S})$

$$
=\frac{\text { Number of matching bands } \times 2}{\text { total number of bands in both isolates }}
$$

Both whole-cell sonicates and culture supernates of all isolates were analysed several times.

\section{Results}

\section{Whole-cell proteins}

Whole-cell proteins were analysed by SDSPAGE. Reproducible gel profiles were obtained 
after staining with Coomassie blue and typical results are shown in fig. 1. Each whole-cell protein profile comprised 49-53 bands, with an average of 52. Visual inspection of gels showed several differences between isolates. However, these were almost entirely due to variations in band intensity, rather than the presence or absence of bands. Calculation of Dice coefficients showed high degrees of similarity between different isolates of MRSA (table I). The results shown are typical of several observations. The least degree of similarity observed, $4.2 \%$, occurred between isolate nos. 272 and 292 , no. 292 possessing 4 more bands than no. 272. Dice coefficients for all other comparisons were higher with 61 pairs of tracks being indistinguishable from each other. All other pairs differed by only 1-3 bands. The average similarity value was $98.9 \%$. No constantly variable polypeptides could be identified. Analyses of whole-cell polypeptides by SDS-PAGE did not discriminate clearly between different isolates.

\section{Exported proteins}

Culture supernates which contained exported proteins were analysed by immunoblotting. Each track contained between 35 and 52 bands, with an average of 43 , slightly fewer than were apparent in whole-cell polypeptide profiles. Visually the isolates could be divided into two groups. The first group consisted of isolate nos. $272,274,278,288,290$, $291,294,51$ and 159 and the second group consisted of isolate nos. $273,277,283,289,292,295,298,83$ and 26. Typical results are shown in fig. 2. Within each group much more variation occurred than between any pairs of tracks in whole-cell polypeptide gels. The spread of percentage similarity values was thus wider than those recorded for whole-cell polypeptide profiles (table II). The least degree of similarity observed, $73.7 \%$, occurred between strain nos. 270 and 83 . Only 10 pairs of tracks were indistinguishable from each other (table II) compared with 61 pairs in Coomassie-blue stained gels (table I). Average percentage similarities shown in

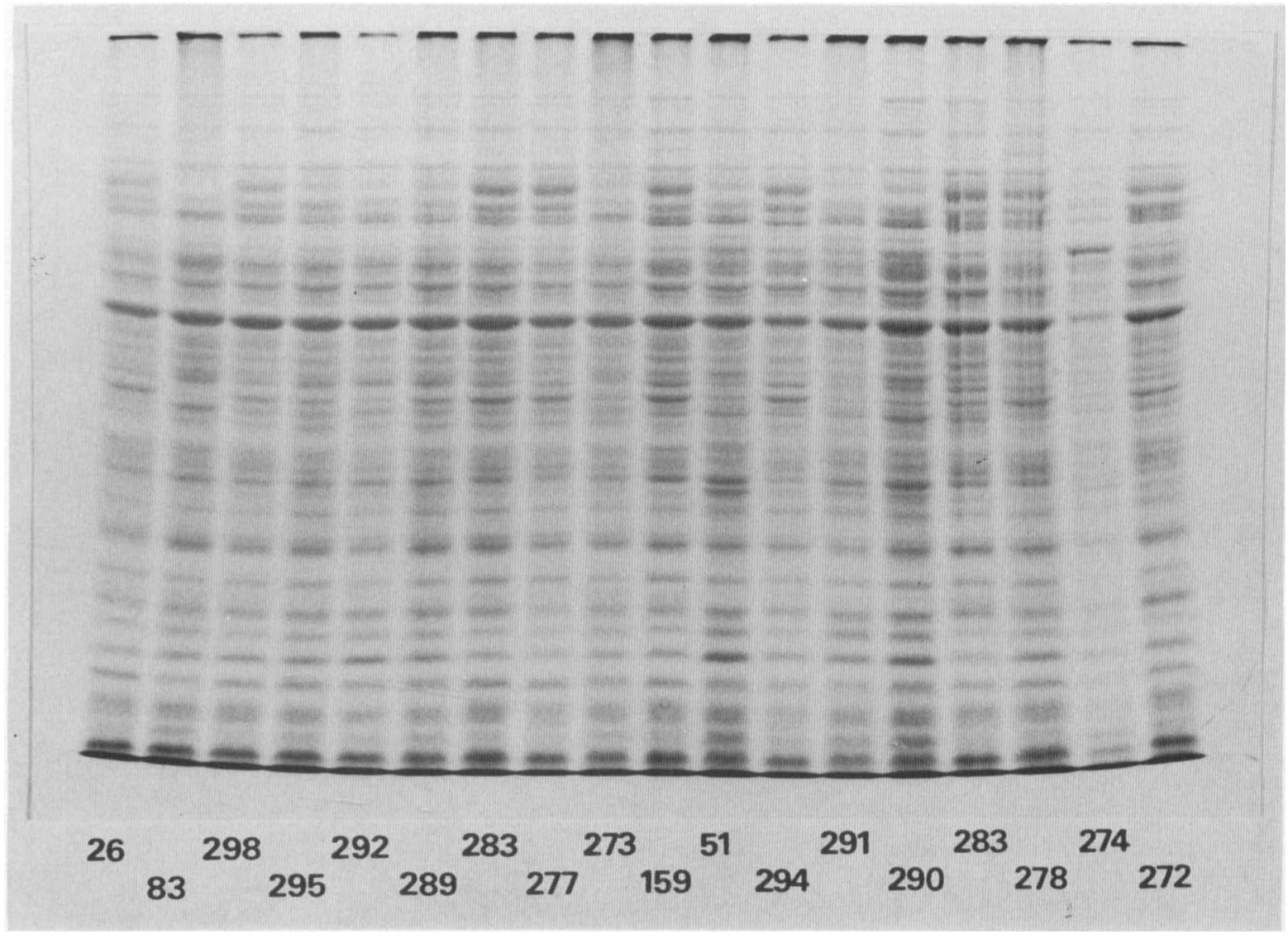

Fig. 1. Whole-cell polypeptide profiles of 18 different isolates of MRSA. Isolate numbers refer to the order in which they were isolated. 
Table I. Average percentage similarity $(\% \mathrm{~S})$ of whole-cell protein profiles of MRSA isolates shown in fig. 1

\begin{tabular}{|c|c|c|c|c|c|c|c|c|c|c|c|c|c|c|c|c|c|c|}
\hline \multirow{2}{*}{$\begin{array}{c}\text { Isolate } \\
\text { no. }\end{array}$} & \multicolumn{18}{|c|}{ Percentage similarity with isolate no. } \\
\hline & 272 & 274 & 278 & 288 & 290 & 291 & 294 & 51 & 159 & 273 & 277 & 283 & 289 & 292 & 295 & 298 & 83 & 26 \\
\hline 272 & & 97.8 & 98.9 & 100 & 98.9 & $97 \cdot 8$ & 98.9 & $97 \cdot 8$ & $98 \cdot 9$ & 97.8 & 97.8 & 98.9 & 98.9 & 95.8 & 98.9 & 98.9 & 98.9 & 100 \\
\hline 274 & & נו & 98.9 & 97.9 & 98.9 & 100 & 100 & 98.9 & 100 & 97.9 & 100 & 100 & 98.9 & $96 \cdot 9$ & 98.9 & 98.9 & 100 & 100 \\
\hline 278 & & & & 100 & 100 & 100 & 100 & 98.9 & 100 & 100 & 100 & 100 & 98.9 & 96.9 & 100 & 98.9 & 98.9 & 98.9 \\
\hline 288 & & & & & 97.0 & 99.0 & $99 \cdot 0$ & 98.0 & 100 & 98.0 & 100 & 100 & $99 \cdot 0$ & $97 \cdot 0$ & $99 \cdot 0$ & 99.0 & 100 & 100 \\
\hline 290 & & & & & & 100 & 100 & 100 & 100 & 100 & 98.9 & 98.0 & 98.9 & 98.9 & 98.0 & 98.9 & 98.9 & 100 \\
\hline 291 & & & & & & & 98.9 & 100 & 100 & 98.9 & 98.9 & 98.9 & 98.9 & 96.9 & 100 & 100 & 98.9 & 100 \\
\hline 294 & & & & & & & & $98 \cdot 1$ & 100 & $98 \cdot 1$ & $99 \cdot 1$ & 100 & $98 \cdot 1$ & 96.6 & $98 \cdot 1$ & $99 \cdot 1$ & $98 \cdot 1$ & $99 \cdot 1$ \\
\hline 51 & & & & & & & & & 100 & 98.2 & 97.3 & $97 \cdot 3$ & 98.2 & 96.5 & 98.2 & 99.0 & 100 & 99.0 \\
\hline 159 & & & & & & & & & & 100 & $99 \cdot 1$ & $99 \cdot 1$ & $98 \cdot 1$ & $96 \cdot 4$ & $98 \cdot 1$ & 97.2 & $98 \cdot 1$ & 100 \\
\hline 273 & & & & & & & & & & & 100 & 100 & 100 & $97 \cdot 0$ & 100 & 100 & 100 & 100 \\
\hline 277 & & & & & & & & & & & & 100 & 100 & 97.0 & 98.9 & 100 & 98.9 & 100 \\
\hline 283 & & & & & & & & & & & & & 100 & 97.0 & 100 & 100 & 98.9 & 100 \\
\hline 289 & & & & & & & & & & & & & & 98.0 & 100 & 100 & 98.9 & 100 \\
\hline 292 & & & & & & & & & & & & & & & 97.0 & 98.0 & 98.0 & 98.0 \\
\hline 295 & & & & & & & & & & & & & & & & 100 & 100 & 100 \\
\hline 298 & & & & & & & & & & & & & & & & & 98.9 & 100 \\
\hline 83 & & & & & & & & & & & & & & & & & & 98.9 \\
\hline 26 & & & & & & & & & & & & & & & & & & \\
\hline
\end{tabular}

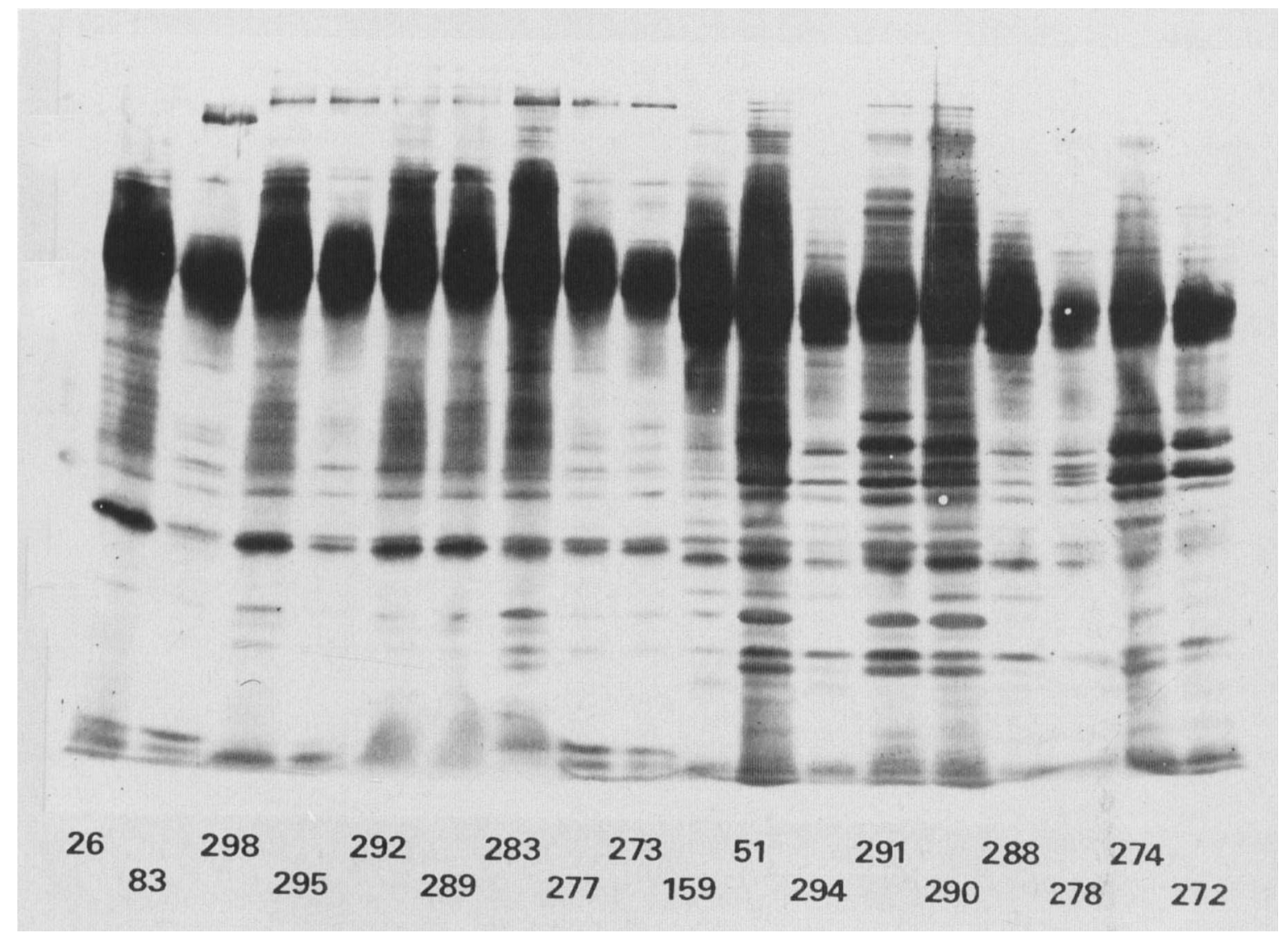

Fig. 2. Immunoblot analysis of culture supernates from the isolates shown in fig. 1. 
Table II. Average percentage similarity $(\% \mathrm{~S})$ of immunoblot profiles of MRSA isolates shown in fig. 2

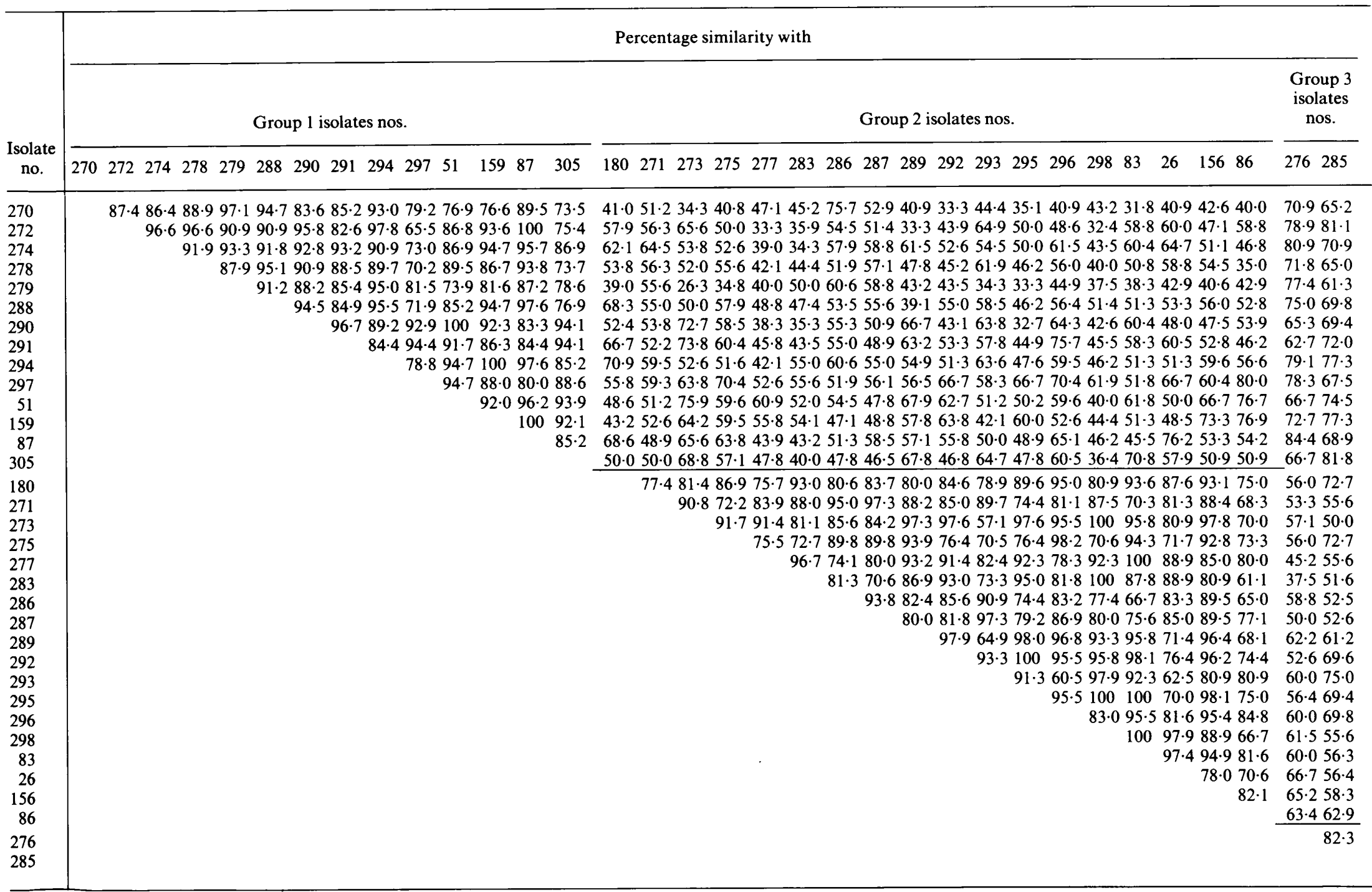


table III were lower than the $98.9 \%$ average recorded for whole-cell profiles. Despite the wide range of percentage similarity values recorded, strains of MRSA could be grouped according to immunoblot profiles. Two main groups were clearly apparent : group 1, comprising 14 isolates and group 2 , comprising 18 isolates. A third minor group made up of only two isolates, nos. 276 and 285 , was also identified (table II).

Within group 1 the spread of percentage similarity values was $65 \cdot 5-100 \%$, with an average similarity of $88.6 \%$. The spread of percentage similarity values within group 2 was $57 \cdot 1-100 \%$, with an average

Table III. Average percentage similarity $(\% \mathrm{~S})$ of exported proteins of MRSA isolates shown in table II

\begin{tabular}{cc}
\hline Group* & $\% \mathrm{~S}$ \\
\hline 1 & 88.6 \\
$1 v .2$ & $53 \cdot 7$ \\
$1 v .3$ & $72 \cdot 8$ \\
2 & 84.9 \\
$2 v .3$ & 58.6 \\
3 & 82.3 \\
\hline
\end{tabular}

* As indicated in table II. similarity of $84.9 \%$. Isolate nos. 276 and 285 (group 3) were $82.3 \%$ similar. Comparisons between the two main groups demonstrated decreased percentage similarity of values, from $26.3 \%$ to $76.9 \%$, with an average similarity $53.7 \%$. Thus the visual designation of MRSA strains to either group 1 or 2 was confirmed because of the degree of dissimilarity between the groups.

Grouping of strains according to immunoblot profile shows concordance with their phage-typing pattern (table IV). Generally, group-1 strains were not susceptible to phages which lysed group-2 strains.

Group 3 was not as clearly defined by immunoblot profiles as groups 1 and 2 . A significant degree of similarity, $72.8 \%$, was observed with group 1 , although similarity with group 2 was only $58.6 \%$. Furthermore, isolate nos. 276 and 285 had different phage-typing patterns (table IV). It is possible that analyses of a larger number of strains could establish group 3 as a discrete set or as a subgroup of group 1.

\section{Discussion}

Analyses of different strains of MRSA by SDSPAGE gave reproducible whole-cell polypeptide profiles. However, due to the high degrees of

Table IV. Results of phage typing of MRSA isolates

\begin{tabular}{|c|c|c|c|}
\hline Group no. & Isolate no. & Phage type (RTD) & Phage type $($ RTD $\times 100)$ \\
\hline 1 & $\begin{array}{l}274 \\
278 \\
279 \\
087 \\
288 \\
270 \\
290 \\
159 \\
272 \\
280 \\
294 \\
291 \\
051 \\
305\end{array}$ & $\begin{array}{l}53 / 85 \\
53 / 85 \\
53 / 85 \\
53 / 85 \\
53 / 85 \\
53 / 85 \\
53 / 83 \mathrm{~A} / 85 \\
53 / 83 \mathrm{~A} / 85 \\
53 / 83 \mathrm{~A} / 85 \\
53 / 75 / 83 \mathrm{~A} / 85 \\
6 / 53 / 75 / 83 \mathrm{~A} / 85 \\
6 / 53 / 54 / 75 / 83 \mathrm{~A} / 85 \\
6 / 47 / 53 / 54 / 75 / 83 \mathrm{~A} \\
29 / 52 / 52 \mathrm{~A} / 79 / 80 / 95 / 53 / 75 / 85\end{array}$ & $\begin{array}{l}29 / 52 / 52 \mathrm{~A} / 79 / 80 / 53 / 54 / 85 / 96 \\
29 / 52 / 79 / 80 / 95 / 53 / 85 / 96 \\
29 / 52 / 52 \mathrm{~A} / 79 / 80 / 95 / 53 / 85 \\
29 / 52 / 52 \mathrm{~A} / 79 / 80 / 95 / 53 / 54 / 85 / 96 \\
29 / 53 / 84 / 85 \\
29 / 79 / 80 / 53 / 85 \\
29 / 52 / 79 / 80 / 95 / 53 / 54 / 83 \mathrm{~A} / 85 / 96 \\
29 / 52 / 52 \mathrm{~A} / 79 / 80 / 53 / 54 / 83 \mathrm{~A} / 85 / 96 \\
53 / 54 / 83 \mathrm{~A} / 85 \\
6 / 47 / 53 / 54 / 75 / 83 \mathrm{~A} / 85 \\
6 / 47 / 53 / 54 / 75 / 83 \mathrm{~A} / 85 \\
6 / 42 \mathrm{E} / 47 / 53 / 54 / 75 / 83 \mathrm{~A} / 85 / 81 \\
29 / 52 / 52 \mathrm{~A} / 79 / 80 / 6 / 42 \mathrm{E} / 47 / 53 / 54 / 75 / 83 \mathrm{~A} / 85 / 81 \\
29 / 52 / 52 \mathrm{~A} / 79 / 80 / 95 / 53 / 75 / 77 / 83 \mathrm{~A} / 85\end{array}$ \\
\hline 2 & $\begin{array}{l}273,277,298,287,156, \\
292,295 \\
275,289,283,293,271 \\
296 \\
026 \\
180,083,086\end{array}$ & $\begin{array}{l}\text { NT } \\
\text { NT } \\
\text { NT } \\
75 / 84 \\
\text { Data not available }\end{array}$ & $\begin{array}{l}75 \\
75 / 84 \\
53 / 75 / 84 \\
52 / 75 / 84\end{array}$ \\
\hline 3 & $\begin{array}{l}285 \\
276\end{array}$ & $\begin{array}{l}\text { NT } \\
53 / 75 / 83 \mathrm{~A} / 85\end{array}$ & $\begin{array}{l}\text { NT } \\
29 / 52 / 52 \mathrm{~A} / 79 / 80 / 95 / 6 / 53 / 75 / 83 \mathrm{~A} / 85\end{array}$ \\
\hline
\end{tabular}

$\mathrm{NT}=$ non-typable. 
similarity observed among these banding patterns, SDS-PAGE analyses of whole-cell extracts could not be used to distinguish between MRSA isolates. In contrast, immunoblotting of extracellular proteins gave characteristic profiles which were used to discriminate different strains of MRSA. The 34 isolates tested could be divided into two main groups and a third minor group. The results show that immunoblotting can provide a rapid, reproducible and sensitive method for characterisation of MRSA.

The development of new methods for typing MRSA is desirable since existing methods often give ambiguous or misleading results. Similar methods to those used in this study have been applied previously. Analysis of whole-cell extracts by ${ }^{35}$ S-SDS-PAGE was unable to discriminate between different isolates of MRSA, and it was therefore concluded that all isolates were closely related (Stephenson et al., 1986). Similarly, immunoblotting of whole-cell extracts has been used to divide a collection of MRSA isolates from the United Kingdom, Australia and Egypt into eight groups (Lee and Burnie, 1988). As reported above, whole-cell polypeptide profiles cannot be used to distinguish MRSA. In comparisons where similarity values approach $100 \%$, different isolates will be indistinguishable from each other. In our hands

\section{REFERENCES}

Barber M 1961 Methicillin-resistant staphylococci. Journal of Clinical Pathology 14: 385-393.

Bradley J M, Noone P, Townsend D E, Grubb W B 1985 Methicillin-resistant Staphylococcus aureus in a London hospital. Lancet 1 : 1493-1495.

Branger C, Goullet P 1987 Esterase electrophoretic polymorphisms of methicillin-sensitive and methicillin-resistant strains of Staphylococcus aureus. Journal of Medical Microbiology 24: 275-281.

Burnette W N 1981 "Western Blotting": electrophoretic transfer of proteins from sodium dodecyl sulphate-polyacrylamide gels to unmodified nitrocellulose and radiographic detection with antibody and radioiodinated protein A. Analytical Biochemistry 112: 195-203.

Burnie J P, Matthews R C 1987 Immunoblot analysis: a new method for fingerprinting hospital pathogens. Journal of Immunological Methods 100: 41-46.

Casewell M W 1986 Epidemiology and control of the "modern" methicillin-resistant Staphylococcus aureus. Journal of Hospital Infection 7 Suppl A: 1-11.

de Saxe M, Cooke M, Mayon-White R, Galbraith N S, Casewell M 1983 Methicillin-resistant Staphylococcus aureus in the UK. Communicable Diseases Report 83/36: 3.

Dice L R 1945 Measures of the amount of ecological association between species. Ecology 26: 297-302.

Dowd G, Cafferkey M, Dougan G 1983 Gentamicin and methicillin resistant Staphylococcus aureus in Dublin hospitals: molecular studies. Journal of Medical Microbiology 16: $129-138$. immunoblots of whole-cell extracts of MRSA did not discriminate clearly between different strains (results not shown), and therefore culture supernates were chosen for analyses.

Use of a single hypoimmune antibody probe resulted in distinct and reproducible banding patterns. Therefore, MRSA isolates can be grouped satisfactorily without the requirement for specific hyperimmune antisera (Lee and Burnie, 1988).

In this study 34 isolates were allotted to three groups on the basis of immunoblot profile: group 1 consisting of 14 strains, group 2 of 18 strains, group 3 of 2 strains. Group 3 may prove to be a subgroup of either of the major groups. To define group 3 more clearly, further analyses of new isolates are required. An increase in sample size would also identify any other overlapping strains and confirm the major groupings. Comparisons with other MRSA isolates, e.g., European and Australian strains, would establish whether the groupings described here are global and could thus provide evidence for or against the clonal origin of MRSA.

We thank the Biomedical Research Committee, Scottish Home and Health Department for financial support, Diane Petrie for technical assistance, Dr J. Coia for supplying the MRSA isolates and Dr R. R. Marples for the phage-typing.

Gelmi M et al. 1987 Antibiotic resistance and plasmids from Staphylococcus aureus from Italian hospitals. Journal of Medical Microbiology 23: 111-118.

Gillespie M T, May J W, Skurray R A 1984 Antibiotic susceptibilities and plasmid profiles of nosocomial methicillin-resistant Staphylococcus aureus: a retrospective study. Journal of Medical Microbiology 17: 295-310.

Grieble H G, Krause S L, Pappas S A, Dicostanzo M B 1981 The prevalence of high-level methicillin-resistance in multiply resistant hospital staphylococci. Medicine (Baltimore) 60: 62-69.

Jevons M P 1961 “Celbenin"-resistant staphylococci. British Medical Journal 1: 124-125.

Krikler S J, Pennington T H, Petrie D 1986 Typing of strains of Staphylococcus aureus by Western blot analysis of culture supernates. Journal of Medical Microbiology 21 : 169-171.

Lacey R W, Stokes A 1979 Studies on recently isolated cultures of methicillin-resistant Staphylococcus aureus. Journal of General Microbiology 114 : 329-339.

Lee W, Burnie J P 1988 Fingerprinting methicillin-resistant Staphylococcus aureus by the immunoblot technique. Journal of Medical Microbiology 25 : 261-268.

Laemmli U K 1970 Cleavage of structural proteins during the assembly of the head of bacteriophage T4. Nature 227:680685.

Locksley R M et al. 1982 Multiply antibiotic-resistant Staphylococcus aureus: introduction, transmission and evolution of nosocomial infection. Annals of Internal Medicine 97: 317324.

Lowry O H, Rosebrough N J, Farr A L, Randall R J 1951 
Protein measurement with the folin phenol reagent. Journal of Biological Chemistry 193: 265-275.

Lyon B R, Iuorio J L, May J W, Skurray R A 1984 Molecular epidemiology of multiresistant Staphylococcus aureus in Australian hospitals. Journal of Medical Microbiology 17: 79-89.

Marples R R, Cooke E M 1985 Report of workshop on methicillin-resistant Staphylococcus aureus held at the headquarters of the Public Health Laboratory Service on 8 Jan 1985. Journal of Hospital Infection 6: 342-348.

Marples R R, Richardson J F, de Saxe M J 1986 Bacteriological characters of strains of Staphylococcus aureus submitted to a reference laboratory related to methicillin resistance. Journal of Hygiene 96 : 217-223.

Pavillard R et al. 1982 Epidemic of hospital-acquired infection due to methicillin-resistant Staphylococcus aureus in major Victorian hospitals. Medical Journal of Australia 1: 451454.

Peacock J E, Moorman D R, Wenzel R P, Mandell G L 1981 Methicillin-resistant Staphylococcus aureus: microbiologic characteristics, antimicrobial susceptibilities, and assessment of virulence of an epidemic strain. Journal of Infectious Diseases 144: 575-582.

Poxton I R, Aronsson B, Möllby R, Nord C E, Collee J G 1984 Immunochemical fingerprinting of Clostridium difficile strains isolated from an outbreak of antibiotic-associated colitis and diarrhoea. Journal of Medical Microbiology 17 : 317-324.

Richardson J F, Chittasobhon N, Marples R R 1988 Supplementary phages for the investigation of strains of methicillinresistant Staphylococcus aureus. Journal of Medical Microbiology 25 : 67-74.

Stephenson J R, Crook S J, Tabaqchali S 1986 New method for typing Staphylococcus aureus resistant to methicillin based on sulphur-35 methionine labelled proteins: its application in an outbreak. British Medical Journal 293: 581-583.

Vickery A M, Beard-Pegler M A, Rountree P M 1983 Strain differentiation in methicillin-resistant Staphylococcus aureus. Pathology 15: 235-240.

Vickery A M, Beard-Pegler M A, Stubbs E 1986 Phage-typing patterns and lysogenicity of methicillin-resistant strains of Staphylococcus aureus from Sydney, Australia, 1965-85. Journal of Medical Microbiology 22 : 209-216.

Witte W, Braulke C 1987 Multiply-resistant and methicillinresistant Staphylococcus aureus strains isolated in the German Democratic Republic in 1985 and 1986. Epidemiology and Infection 99: 603-612.

Witte W, Nguyen V D, Dunnhaupt K 1986 Methicillin-resistant Staphylococcus aureus (MRSA) in the German Democratic Republic. Incidence and strain-characteristics. Journal of Hygiene, Epidemiology, Microbiology and Immunology (Prague) $30: 185-193$. 